\title{
An Assessment of Financial Performance and Service Facility Improvement after Merger and Acquisition of Financial Institutions of Nepal
}

Ganesh Bajgai

PhD Scholar (MUR1302991), Mewar University, Rajasthan, India

Prof. Dr. Radheshyam Pradhan

Supervisor, Mewar University, Rajasthan, India

Email: rspradhan@uniglobe.edu.np

Corresponding Author

Ganesh Bajgai

Email: ganeshbajagain@gmail.com

DOI: https://doi.org/10.3126/irjmmc.v2i2.38144

Received: March 15, 2021; Revised \& Accepted: March 26, 2021; Published: June 30, 2021

(C) Copyright: Bajgai (2021).

\begin{abstract}
Merger and acquisition are one process to integrate the two or more similar types of institutions into one institution. Basically, more banking sectors are gone in merger and acquisition in Nepal. Nepal Rastra Bank has introduced the Merger by law-2068 BS with the objective of reducing the number of BFIs, enhancing financial stability and promoting public confidence on the banking sector, which encouraged and compelled the banking sectors to proceed the merger and acquisition process for their long-term sustainability. Considering this status, the study was conducted to identify the impact of merger and acquisition on financial performance and service quality of financial institutions of Nepal. The study was conducted covering the category $A$ and $B$ bank which were established after merger and acquisition process. It was a cross-sectional study conducted among the 385 employees of banking sectors. The result shows that the financial performance and service quality of both types of banks (category $A$ and B) was significantly difference in post-merger situation because the p value of $t$ test was less than .05 significant level.
\end{abstract}

Keywords: Financial institutions, Merger \& Acquisition, Performance, Service quality 


\section{INTRODUCTION}

The term 'merger\& acquisition' refers to the buying \& selling- acquiring \& disposing- of both private business \& public companies. In the case of the acquisition of a publicly traded company, this may also be referred to as a takeover(Creighton, 2013). In M\&A acquired company deliberately delivers its Assets and Liabilities in the hands of acquiring company. Many companies choose to select integration with another entity to safeguard its business from downfall. Moving forward with M\&A with successful similar business is a winning strategy (Ansari \& Mustafa, 2018).

There is a positive impact of merger and acquisition on the financial performance and service quality of financial institution in post-merger phase. A previous study revealed that liquidity, profitability and investment ratios of the banks are positively and significantly increased the performance after M\&A. Nevertheless, the solvency ratios indicate negative effects which are mainly based on the fact that after undergoing M\&A the acquiring bank has to deal with the greater amount of debt burden as compared to pre-M\&A(Muhammad, Waqas, \& Migliori, 2019). Similarly, result of another study shows that merger has improved performance of Jordan Ahli bank with a total percentage (66.67\%) (Hroot, 2015). Regarding the service quality of financial institutions in post-merger phase, a previous study conducted on "The Impact of Mergers and Acquisitions on Service Quality of Banks in Ghana: Case Study of Eco-bank and Access Bank Ghana" indicated that M \& A had positive impact on overall service quality. The conclusion drawn by the researchers indicates that mergers and acquisitions offer superior growth and financing option for banks. This in turn promotes economic efficiency through improvements in costs and services delivery(Yeboah, Asirifi, \& Ampadu, The Impact of Mergers and Acquisitions on Service Quality of Banks in Ghana: Case Study of Ecobank and Access Bank Ghana, 2015).

A study of Karn concluded thatNepalese banks were benefited and did significant growth in their operations and minimized their expenses to a considerable extent after mergers and acquisitions. The poor performing banks have been merged and have become more competitive and standard (Karn, 2020 ). It is well accepted that consolidation and acquisition (Merger \&Acquisition) is one of the most effective measures to strengthen the financial system. The Government of Nepal has been promoting integration as a means of achieving efficiency through the economy of scale and breadth by facilitating the integration between weak and strong banks to create a more efficient and stable business(Baniya \& Adhikari, 2018). Nepal Rastra Bank (NRB) has introduced the Merger by law - 2068 BS with the objective of reducing the number of BFIs, enhancing financial stability and promoting public confidence on the banking sector (Shrestha, Thapa, \& Phuyal, 2017). In the study of Bhatta, he had stated that the mergers led to changes in bank's share ownership. Bank's efficiency increases with more competent and merged ideas (Bhatta, 2016). Similarly, another study conducted in Nepal by Ojha \& Walsh have concluded that merger and acquisition of financial institutions in Nepal has been promoted in the recent years and is in increasing trend. It is because Merger in the recent years has helped most 
of the financial institutions to increase the capital as well as help them to become more competitive (Ojha \& Walsh, 2016). The study 'Motives for Mergers and Acquisitions in the Nepalese Perspective' aims to identify the motives of mergers and acquisitions in the Nepalese financial sector (Pathak, 2016). The study concludes that (i) meeting the regulatory requirement of paid-up capital, (ii) realization of economies of scale and scope, and (iii) generation of efficiencies due to synergistic gains are the three most important motives for mergers. This is the first study of its kind in the Nepalese context. Similarly, the study of KafleBishal had explored the three reasons: liquidity crunch, capital requirement, and open financial market that forced the Nepalese Banking Sector to go into the process of Merger and Acquisition (Bishal, 2013).

\section{OBJECTIVE OF THE STUDY}

In the review of Nepalese related study, they were not clearly measured the impact of merger and acquisition on financial performance and service quality of baking sectors, so considering that gap, the present study was conducted with the objective to identify the impact of merger and acquisition on financial performance and service quality of financial institutions of Nepal.

\section{HYPOTHESIS OF THE STUDY}

Based on the general objective of this study, it has prepared two null hypotheses as below:

H01: There was no significant difference between Category A and Category B Banks in their financial performance after merger and acquisition.

H02: There was no significant difference between Category A and Category B Banks in their service quality after merger and acquisition.

\section{MATERIALS \& METHODS}

The study was a cross-sectional study conducted among the 385 employeesworking in the banking sectors. There were 155 (40.3\%) respondents from category A bank and 230 (59.7\%) respondents participated from the category B bank. Similarly, the distribution of position shows that higher percentage (57.1\%) of the respondents are in the position of Officer, followed by Assistant Manager with a percentage of (27.3\%), Supervisor (9.1\%) and Senior Manager (6.5\%). It is a quantitative study so structured survey questionnaire was used to collect the data and statistical analysiswas done to analyze the data. The respondents were selected by using the simple random sampling design. Researcher had visited to those Banks which was established after merger and acquisition. The study had prepared the questionnaire and discussed with the respondents. Five-point Likert's scale was used to collect the opinion of respondents. The study had calculated the percentage, mean, and independent sample t-test to analyzethe data. There were two types of respondents from category A bank and category B bank. So, it has run the t- 
test to identify the mean difference between A and B class bank in their financial indicators and service quality (Table 3)

\section{RESULT \& DISCUSSION}

One of the main objectives of this study was to analyze the financial performance and service quality of BFIs after merger because bank and financial institutions go in process of merger and acquisition with the objective to enhance the institutional capacity, increase the amount, maximize the profit, improve the quality of service, increase the market size. In this ground, the study discussed with the respondents to know their response. The distribution of responses is presented in the below tables.

\section{Financial Performance of BFIs after merger}

The data presented in Table 1 shows the response of the participants based on their level of agreement and disagreement to the given financial indicators that show the financial performance of BFIs after merger.

Table 1: Financial Performance of BFIs after merger

Do you agree that the followingFinancial Indicators of Banks are improved after the Merger?

\begin{tabular}{lllllll} 
Earnings per Share (EPS) & 1.0 & 4.4 & 14.8 & 55.3 & 24.4 & 3.9766 \\
Market Value per Share (MPS) & 1.0 & 9.9 & 17.9 & 50.4 & 20.8 & 3.8000 \\
Price Earnings Ratio & .8 & 8.8 & 21.0 & 50.4 & 19.0 & 3.7792 \\
Capital Debt (CD) Ratio & & 7.0 & 12.7 & 52.2 & 28.1 & 4.0130 \\
Capital Adequacy Ratio & .5 & 7.8 & 15.8 & 48.6 & 27.3 & 3.9429 \\
Decreasing of Non-Performing Loan to Total Loan & .5 & 8.8 & 33.8 & 44.7 & 12.2 & 3.5922 \\
Return on Assets (ROA) & .3 & 9.1 & 26.5 & 55.8 & 8.3 & 3.6286 \\
Return on Equity (ROE) & .3 & 6.0 & 26.2 & 60.0 & 7.5 & 3.6857 \\
Net Profit Margin (NPM) & 1.0 & 8.6 & 26.0 & 58.7 & 5.7 & 3.5948 \\
Debt to Equity Ratio (DER) & & 7.5 & 30.6 & 55.3 & 6.5 & 3.6078 \\
liquidity ratios and current ratio (CR) & & 5.5 & 29.9 & 57.7 & 7.0 & 3.6623 \\
\hline
\end{tabular}

Source: Field Survey, 2020

As per the data presented in above Table, Earnings Per Share (EPS) was agreed by $(55.3 \%)$ as a form of financial indicator that improves bank financial performance and service, the mean of the response was 3.9766. Market Value per Share (MPS) was agreed to be a positive indicator that improves bank financial performance and service by $(50.4 \%)$, the mean of the response was 3.8000. Price Earnings Ratio was agreed by (50.4\%) of the respondents as a form of financial indicator that improves bank financial performance and service, the mean of the response was 3.7792. Capital Debt (CD) Ratio was agreed by $(52.2 \%)$ as a form of financial indicator that improves bank financial performance and service, the mean of the response was 4.0130.

Capital Adequacy Ratio was agreed by over forty-eight per cent (48.6\%), as a form of financial indicator that improves bank financial performance and service, the mean of the 
response was 3.9429. Decreasing of Non-Performing Loan to Total Loan was agreed by (44.7\%) as a form of financial indicator that improves bank financial performance and service, the mean of the response was 3.5922 .

Return on Assets (ROA) was agreed by over fifty-five per cent (55.8\%), as a form of financial indicator that improves bank financial performance and service, the mean of the response was 3.6286. Return on Equity (ROE) was agreed by $(60.0 \%)$, as a form of financial indicator that improves bank financial performance and service, the mean of the response was 3.6857. Net Profit Margin (NPM) was agreed by over fifty-eight per cent (58.7\%), as a form of financial indicator that improves bank financial performance and service, the mean of the response was 3.5948. Debt to Equity Ratio (DER) was agreed by over fifty-five per cent $(55.3 \%)$, as a form of financial indicator that improves bank financial performance and service, the mean of the response was 3.6078. liquidity ratios and current ratio (CR) was agreed by over fifty-seven per cent (57.7\%), as a form of financial indicator that improves bank financial performance and service, the mean of the response was 3.6623 .

In general, all the financial indicators (11 indicators) had got around 4 mean value which is close to the agree response. It indicates that there was positive improvement in financial indicators of selected financial institutions after merger and acquisition. It has encouraged the other institutions also to go in process of merger and acquisition to enhance the financial strength of their institution. The findings of this study are positively supported by the findings of other previous Nepalese study also. The statistical results of one study conducted by Dr. Prakash Shrestha show that out of total respondents the commercial banks personnel (mean = 3.36; S.D. $=0.17$ ) are agreed that M\&A affect the liquidity position of the bank. The personnel of development bank (mean $=2.61$; S.D. $=0.53$ ) are agreed that M\&A has positive impact on performance of banking institution. Similarly, the same personnel of development bank are agreed $($ mean $=3.61 ;$ S.D. $=0.17)$ are agreed M\&A increase the capital base of BFIs $\&$ thus develop the competent capabilities. Likewise, personnel of finance companies agreed (mean $=$ 3.00; S.D. $=0.21)$ that M\&A promote financial capability and competitiveness through shared skills. In conclusion, the study indicates that merger and acquisition affect the liquidity position of the bank. The results also show that M\&A practices increase the capital base of BFIs \& thus develop the competent capabilities(Shrestha D. P., 2019). In the case of international study also, there was significant improvement in financial indicators after merger. Obaid-ullah, Sabeehullah\& Usman(2010) investigated the effects of mergers on the financial performance of Atlas Investment and Al-Faysal Investment Bank Ltd from Pakistan. Study employed three financial measures; profitability and earning, capital adequacy and solvency. It found that for Faysal bank limited average improvement was recorded in the post-merger period. It is concluded that in post-merger period of sample both the banks improved their financial performance.

In contrast to the above findings was reported in the study of Shrestha, Thapa, \& Phuyal (2017). A Comparative Study of Merger Effect on Financial Performance of Banking and Financial Institutions in Nepal makes an attempt to analyze the financial performance of merged 
banking and financial institutions relative to their pre-merger performance, and assess the perception of the stakeholders towards merger. This study had used the financial indicators to find the performance impact of mergers. The study focused that merger impacts performance positively when larger and stable parties such as commercial banks act as bidders as opposed to the merger between smaller BFIs mainly other than commercial banks as bidder. This study found that the loan quality significantly deteriorates after merger in most of the cases and profitability measured in terms of ROA and ROE was adversely affected in most of the cases after the merger. Therefore, it has suggested that the merger should not be considered as the definite solutions to overcome the challenges faced in the market enough evaluation is needed to select the right partners before executing the merger(Shrestha, Thapa, \& Phuyal, 2017). The finding was slightly differed with the finding of present study because the present study had shown the significant improvement in the ROA and ROE in post-merger phase.

\section{Service Quality to Customer in Post-Merger Phase}

The data presented in table 2 shows the response of the participants based on the service quality to customer in post-merger phase. The table indicates the level of satisfaction of the customers based on the type of service received after the merger of the banks.

Table 2: Service Quality to Customer in Post-Merger Phase

\begin{tabular}{lllllll} 
& SD & D & N & A & SA & Mean \\
\hline High interest in deposit & 1.6 & 51.7 & 26.2 & 17.9 & 2.6 & 2.6831 \\
Low interest in loan & 2.3 & 50.9 & 30.1 & 14.5 & 2.1 & 2.6312 \\
Decrease in service charge of loan & & 23.4 & 51.4 & 23.1 & 2.1 & 3.0390 \\
Number of ATM counter and branch has been increased & & 6.2 & 22.6 & 50.6 & 20.5 & 3.8545 \\
Adoption of new technology & .3 & 5.2 & 12.7 & 57.7 & 24.2 & 4.0026 \\
No charge and fees monopoly & & 24.7 & 14.8 & 47.0 & 13.5 & 3.4935 \\
\hline
\end{tabular}

Source: Field Survey, 2020

One of the main motivations of customer to get the high interest rate in their saving amount. Financial institutions are also doing marketing focusing the interest rate in saving amount but as per the data presented in Table 2, more than half of the respondents $(51.7 \%)$, disagreed to having received high interest in deposit as per the service quality to customer in post-merger phase, with the mean of response of 2.6831. The response of respondents indicates that there was no satisfactory improvement in interest rate of saving amount of customers after merger. If bank and financial institutions can increase in interest rate of saving amount, decrease in loan amount and can improve other technical facilities for the customers then it can attract the customer of banks and financial institutions. Similarly, more than fifty per cent $(50.9 \%)$ of the participants disagreed to having received Low interest in loan as per the service quality to customer in post-merger phase, with the mean of response of 2.6312. Likewise, more than half of the respondents, $(51.4 \%)$ of the participants were neutral to getting a 'Decrease in service charge of loan' as per the service quality to customer in post-merger phase, with the mean of response of 
3.0390. The low interest rate in loan and other service charge are the main attraction of customers. It can also support to increase the level of customer satisfaction so BFIs are suggested to consider these services to increase the number of customers.

Likewise, for the statement, 'Number of ATM counter and branch has been increased' more than fifty per cent $(50.6 \%)$ of the respondents agreed as per the service quality to customer in post-merger phase, with the mean of response of 3.8545. More than fifty-seven per cent $(57.7 \%)$ agreed there was 'Adoption of new technology', as per the service quality to customer in post-merger phase, with the mean of response of 4.0026. No charge and fees monopoly, was agreed by $(47.0 \%)$ of the respondents as improvement as per the service quality to customer in post-merger phase, with the mean of response of 3.4935 .

One previous Nepalese study also shows the positive improvement in the service quality of BFIs after merger and acquisition. Study conducted by Krishna Prasad Sharma suggested that the merger program was successful from customers' point of view in Nepal because it had benefited them through economies of scale, expansion of working area and advancement in technology. Another perspective regarding the service quality of banks in post-merger found that customers were enjoying competitive interest rate due to the enhanced capital base(Sharma, 2018). Similar result was shown by an international study also conducted to find out how Mergers \& Acquisitions have impacted service quality of consolidated banks in Ghana. The result shows that in terms of the various service quality dimensions considered, convenience was the key driver of service quality followed by responsiveness as indicated by their relatively wider margin of change. This suggests that customers were experiencing marked improvement in the foregoing service quality dimensions as a result of the Merger and Acquisition (Yeboah, Asirifi, \& Ampadu, 2015).

One previous study shows the contract result than above study. Study conducted by Burhan Ahmad Mtengwa\&Janeth A. Malleo on "Stakeholder's Perception on Quality of Mergers and Acquisitions in Tanzania" revealed that all dimensions of mergers and acquisition service sector were not satisfactory to stakeholders. Gap score analysis indicated negative values on four dimensions namely job creation, market monopoly, customer satisfaction and shareholders position (employees feeling of betray by their employer, less job creations, a shift of stakeholder's bargaining power and less customers satisfaction) meaning that all dimensions needed improvements(Mtengwa \& Malleo, 2018).

The results of current and previous study shows that there was both positive and negative impact of merger and acquisition on service quality of financial institutions. The service quality depends upon the management skill of senior management of concerned institutions.

\section{Differences of financial performance and service quality between the Category $A$ and B Bank}

The study had analyzed the mean differences between category A and B bank regarding their response on differences of financial performance and service quality. The mean value of 
category A bank is 42.1419 and mean of Category B bank is 40.7043 based on the financial performance. The mean value of A bank is 20.4710 and mean of Category B bank is 19.1870 based on their service quality. Comparatively, the mean value of Category A bank is higher than the Category B in financial performance and also in regard of service quality. It indicates that financial performance and service quality of category A bank was better than the category B in post-merger situation. 
Table 3: Differences of financial performance and service quality between the Category A and B Bank Group Statistics

\begin{tabular}{llllll} 
& Category of Bank & N & Mean & Std. Deviation & Std. Error Mean \\
\hline \multirow{2}{*}{ Financial performance } & A & 155 & 42.1419 & 4.92072 & .39524 \\
\multirow{3}{*}{ Service quality } & B & 230 & 40.7043 & 4.73392 & .31215 \\
& A & 155 & 20.4710 & 2.47142 & .19851 \\
& B & 230 & 19.1870 & 2.47517 & .16321
\end{tabular}

Independent Samples Test

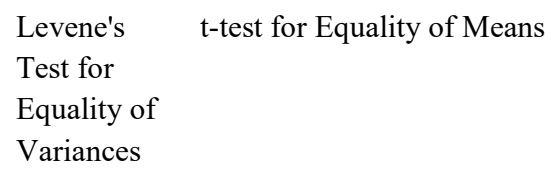

Source: Field Survey, 2020

The statistical analysis of Levene's Test for Equality of Variances shows that there was no significant difference between category $A$ and $B$ because $p$ value is 0.816 which indicates the equal variances was assumed between the category $\mathrm{A}$ and $\mathrm{B}$ bank for the financial performance. From the $\mathrm{T}$ test, there was significant difference between the category A and B bank regarding their response on differences of financial performance because the $p$ value is .004 which is less than .05 significant level at $95 \%$ confidence interval. The result has rejected the $\mathrm{H} 01$ of this study.

Similarly, the statistical analysis of Levene's Test for Equality of Variances shows that there was no significant difference between category A and B because $\mathrm{p}$ value is .311 which indicates the equal variances was assumed between the category $\mathrm{A}$ and $\mathrm{B}$ bank for the service quality. As per the T-test, there was significant difference between the category A and B bank regarding their response on differences of service quality because the $\mathrm{p}$ value is .000 which is less than .05 significant level at $95 \%$ confidence interval. The result has rejected the $\mathrm{H} 01$ of this study.

In general, the financial performance and service quality of both types of banks (category $\mathrm{A}$ and B) was significantly difference in post-merger situation because the $\mathrm{p}$ value of $\mathrm{t}$-test was less than .05 significant level. 


\section{CONCLUSION}

The study shows that indicators like Earnings Per Share (EPS), Market Value Per Share, Price Earnings Ratio and Capital Debt Ratio improves bank's financial performance and service. The major impacts of the merger and acquisitions on the performance of the banking industry in Nepal are achievement of financial growth, better policies, increase in the size and strength of the BFIs, become financially sound, capital enhancement and increase in the profitability. In general, the financial performance and service quality of both types of banks (category A and B) was significantly difference in post-merger situation because the $\mathrm{p}$ value of $\mathrm{t}$-test was less than .05 significant level. The study had discussed only in the financial performance and service quality in post-merger phase so future researcher can explore the new knowledge by doing the study on the level of employees' satisfaction in post-merger phase.

\section{REFERENCES}

Ansari, M. A., \& Mustafa, M. (2018). An analytical study of impact of merger \& acquisition on financial performance of corporate sector in India. Journal of Management Research and Analysis, 113.

Baniya, R., \& Adhikari, S. (2018). Mergers and Acquisitions of the Financial Institutions:

Factors Affecting the Employee Turnover Intention. NRB Economic Review, 31-50.

Bhatta, M. (2016). Effect of bank merger on the shareholders wealth and post-merger situation of Nepalese banking industry. Information Management and Business Review, 8(4), 50.

Bishal, K. (2013, February 27). Mergers and Acquisitions in Nepalese Banking Sector.

Creighton, K. (2013). Introduction to Mergers \& Acquisitions. Trends.be.

Hroot, Y. A. (2015). Pre and Post-Merger Impact on Financial Performance: A Case Study of Jordan Ahli bank . European Journal of Business and Management, 56.

Karn, D. S. (2020 , June ). Mergers and Acquisitions of Banking Sector in Nepal: A Current Issues. International Journal of Business and Management Invention (IJBMI), 9(6), 5659. doi:DOI: 10.35629/8028-0906015659

Mtengwa, B. A., \& Malleo, J. A. (2018). Stakeholder's Perception on Quality of Mergers and Acquisitions in Tanzania . International Journal of Academic Research in Business \& Social Science, 1109.

Muhammad, H., Waqas, M., \& Migliori, S. (2019). THE IMPACT OF M\&A ON BANK'S FINANCIAL PERFORMANCE: EVIDENCE FROM EMERGING ECONOMY. Corporate Ownership \& Control, 52. 
Ojha, S., \& Walsh, j. (2016). Merger Policy and its impact on Nepalese banks. International Review of Management and Development Studies, 1(2), 117-134.

Pathak, H. P. (2016). Motives for mergers and acquisitions in the Nepalese perspective. Economic Literature, 13(1), 8-18.

Sharma, K. P. (2018). The Impact of Merger and Acquisition on Customer Satisfaction in PostMerger Phase in Banking Sector of Nepal. The Journal of Nepalese Business Studies, 57.

Shrestha, D. P. (2019, June 30). Effect of Merger and Acquisition Practice in Financial Institutions of Nepal. Journal of Balkumari College, VIII, 5-9.

Shrestha, M., Thapa, R., \& Phuyal, R. (2017). A Comparative Study of Merger Effect on Financial Performance of Banking and Financial Institutions in Nepal. Journal of Business and Social Sciences Research, 2 (1 and 2), 47-68.

Ullah, O., Ullah, S., \& Usman, A. (2010). Post-merger performance of Atlas Investment and AlFaysal Investment Bank Ltd. in Pakistan. International Research Journal of Finance and Economics, 168-174.

Yeboah, J., Asirifi, E. K., \& Ampadu, S. (2015, November 25). The Impact of Mergers and Acquisitions on Service Quality of Banks in Ghana: Case Study of Ecobank and Access Bank Ghana. International Journal of Business and Management, 10(12). doi:doi:10.5539/ijbm.v10n12p167 